\title{
SOIL EROSION BETWEEN BIRCHS INLET AND ELLIOTT BAY, SOUTHWESTERN TASMANIA
}

\author{
by M. Pemberton
}

(with two tables, one text-figure and one plate)

PEMBERTON, M., 1987 (31:x): Soil erosion between Birchs Inlet and Elliott Bay, southwestern Tasmania. Pap. Proc R. Soc. Tasm. 122(2): 109-114. https://doi.org/10.26749/rstpp.122.2.109

ISSN 0080-4703. Chemistry and Soils Section, Department of Agric uiture, Hobart, Tasmania.

Organic soils (peats) in areas of southwestern Tasmania have been degraded by fire and subsequent erosive processes. An area affected by frequent firing has been examined and mapped to demonstrate the extent and severity of erosion. A high fire frequency is likely to lead to increased peat loss, a decrease in height and cover of vegetarion and ultimately to areas denuded of peat. Implications for land management are discussed.

Key Wørds: søil erøsiøn, organic søil, peat, søuthwestern Tasmania, søil eresion mapping, land degradation.

\section{INTRODUCTION}

Extensive areas of southwestern Tasmania are covered by blanket bogs that are particularly vulnerable to degradation by burning. Gore (1983) describes blanket bogs as organic soils or peats that are not confined to depressions but cover undulating terrain in response to a very humid climate. This paper examines the extent, severity type and topography location of erosion in an area south of Birchs Inlet. The literature contains no detailed accounts of soil erosion in southwestern Tasmania although nutrient loss following peat combustion has been recorded (Bowman 1980, Bowman et al. 1986, Brown \& Podger 1982). Bowman \& Jackson (1981) have commented on peat destruction, leaching of ash and overall decrease in nutrient levels following a prescribed burn of sedgeland/heath in this region. Wein (1981) has documented peat loss associated with burns in northwestern Tasmania and Kirkpatrick \& Dickinson (1984) examined loss of surface soil organic matter after fire in Tasmanian alpine areas.

\section{THE STUDY AREA}

The study area is situated south of Macquarie Harbour and extends from Elliott Bay in the south to Birchs Inlet in the north, covering an area of $550 \mathrm{~km}^{2}$ (fig. 1). Interbedded Tertiary gravels, sands, silts, clays and lignite bands occur across the northern extent of the area (i.e. north of Moores Valley airstrip) while Ordovician siliceous sediments are restricted to the area between Mount
Osmund and the Wanderer River. East and south of Mount Osmund acid to intermediate rocks of the Cambrian Mount Read Volcanics occur while Cambrian granites are restricted to the area around Elliott Bay. The topography, which forms part of the lower coastal surface defined by Davies (1959), covers an altitudinal range of 0 to $400 \mathrm{~m}$. Swampy conditions prevail around most water courses and the rest of the area is dominated by undulating plains or low, terraced slopes and plateaux.

Organic soil covers most of this terrain. Alluvial deposits are restricted to water courses and sands are associated with dunes around Elliott Bay. Organic soils have fibrous surface horizons which are usually 5 to $15 \mathrm{~cm}$ deep and reddish brown in colour, with underlying muck peat horizons that are between 10 and $20 \mathrm{~cm}$ deep and brown to grey in colour. The muck peats often grade into sandy gravels at approximately $30 \mathrm{~cm}$. North of Moores Valley unconsolidated gravels, sands, silts or clays of Tertiary age may underlie the organic soils. In very poorly drained situations peats may reacin $150 \mathrm{~cm}$ in depth.

Sedgeland/heath covers most of the study area with Gymnoschoenus sphaerocephalus, Melaleuca squamea, M. squarrosa, Leptospermum nitidum, Restio spp. and Sprengelia incarnata common, while scattered taller individuals of Hakea epiglottis and Banksia marginata often occur. Scrui) has developed in some gullies with riverine rainforest along larger rivers (Davies 1983, Gibson 1986). Average annual precipitation in the study area varies between 1800 and $2000 \mathrm{~mm}$.

Two bands of Aborigines, one from Port Davey, the other from Low Rocky Point frequented 


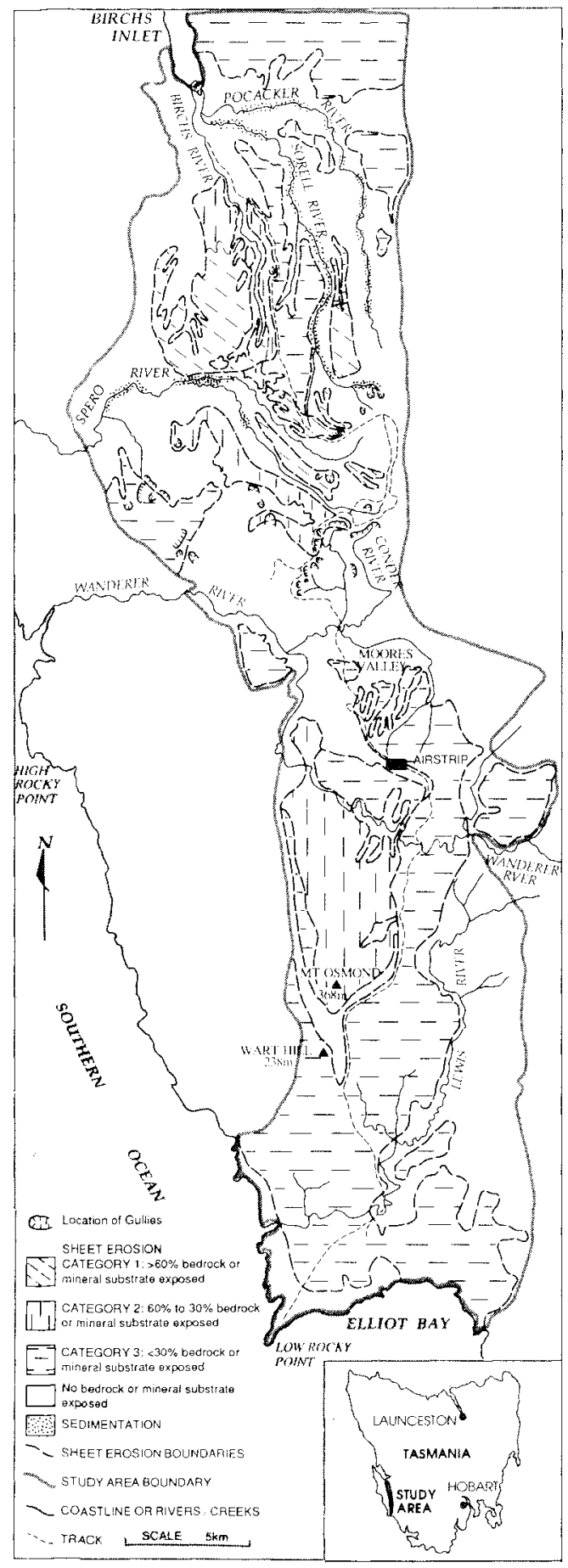

FIG. I Extent and severity of various forms of soil erosion between Birchs Inlet and Elliott Bay, southwestern Tasmania. the area between Elliott Bay and Birchs Inlet and kept it open by firing (Jones 1974). Most of these people were removed from the area in the 1830's. In the following years various explorers, surveyors, whalers and piners visited the region and commented on the open nature of the country (Gowlland \& Gowlland 1975). It is likely that occasional firing occurred over the next one hundred years. Most of the recent fires have been attributed to fishermen, Commonwealth and Tasmanian Government employees and people involved with mineral exploration. For an indication of the location and approximate area affected by recent fires in the study area see table 1 .

The study ared, part of the South West Conservation Area, is managed by the Tasmanian Department of Lands, Parks and Wildlife. Mineral exploration is occurring in the region due to interest in the massive sulphide deposits associated with the Mount Read Volcanics (Large et al. 1987).

\section{METHODS}

To assess soil degradation, the study area was initially examined using aerial photographs (1:40000 black and white photographs, flown 1984). Field inspection was conducted as part of the South West Land Systems Survey (Pemberton, in press). During this survey, information was collected on soils, soil erosion, vegetation (using TASFORHAB - see Peters 1984) and general site characteristics (e.g. topographic position, slope and drainage).

Aerial photographs and 1:100000 topographic map sheets were used for detailed mapping of erosion types, as outlined in table 2. Estimates of percentage bedrock or mineral substrate exposure was made for each square kilometre to produce figure 1 .

Sedimentation of creeks and rivers often occurs in the vicinity of sheet or gully eroded areas. Areas of sedimentation are shown in figure 1.

\section{RESULTS}

The extent of the various forms of erosion and sedimentation are shown in figure 1 , and the extent of sheet erosion is presented in table 2 . Sheet erosion has affected just over $42 \%\left(235 \mathrm{~km}^{2}\right)$ of the study area. Ground checks have confirmed the existence of sheet erosion over extensive areas where peat has not been completely removed. It appears that much of the study area, with the 
TABLE 1

\section{Recent Fires in the Study Area*}

\begin{tabular}{llc} 
Date & \multicolumn{1}{c}{ Location } & $\begin{array}{c}\text { Approx. area } \\
\text { burnt }\left(\mathbf{k m}^{2}\right)\end{array}$ \\
\hline $1969-70$ & North from Low Rocky point & 20 \\
$1973-74$ & South from Birchs Inlet to & 90 \\
1975 & Moores Valley & 55 \\
1976 & Northeast region & 25 \\
$1977-78$ & Western edge & 10 \\
1985 & Southwestern edge & 335 \\
\hline
\end{tabular}

* From unpubl. map, Department of Lands, Parks and Wildlife.

exception of some swamp and coastal environments, has been seriously degraded by this form of erosion. Conservative estimates suggest that at least $50 \mathrm{~km}^{2}$ is almost devoid of soil.

The most severe degradation has occurred between Birchs Inlet and the Wanderer River, where peat horizons overlie Tertiary deposits. These peat horizons have been removed by wind, water and fire from well drained slopes, ridges and crests. They are more susceptible to degradation than organic soil of adjoining lowland swamps because they are more exposed and tend to dry out more rapidly. Sheet erosion has left most of the steeper country with a denuded appearance (plates $1 \mathrm{C}$ and 1D) and field observations suggest up to $0.3 \mathrm{~m}$ of peat have been lost from areas where bedrock is exposed.

Serious gully erosion appears to be restricted to the area between the Conder and Spero Rivers and to a small region north of the Spero River. The gullies typically occur at the headwaters of drainage lines and often coalesce to form larger units which can be over $10 \mathrm{~m}$ deep and $50 \mathrm{~m}$ wide with gently inclined floors but precipitous walls.

Large volumes of material from gully and sheet erosion have probably contributed to an increased rate of sedimentation on alluvial flats along sections of the Birchs, Sorell, Spero and Pocacker Rivers where decreased stream gradients and velocities favour sediment deposition.

TABLE 2

Erosion Types, and Areas Affected by Sheet Erosion

\begin{tabular}{|c|c|c|c|}
\hline Type & Description & $\begin{array}{l}\text { Areas affected } \\
\qquad\left(\mathrm{km}^{2}\right)\end{array}$ & $\begin{array}{r}\text { Percentage } \\
\text { of study area }\end{array}$ \\
\hline Gully & $\begin{array}{l}\text { Erosion that forms large gullies at headwaters of drainage lines } \\
\text { (plates } 1 \mathrm{~A} \text { and } 1 \mathrm{~B} \text { ) }\end{array}$ & & \\
\hline \multirow[t]{5}{*}{ Sheet } & $\begin{array}{l}\text { Removal of soil layers by fire, wind and water (plates IC and 1D). } \\
\text { Sheet-eroded areas were identified where bedrock or mineral } \\
\text { substrate exposure was evident. Sheet erosion has been classified } \\
\text { into: }\end{array}$ & & \\
\hline & Category $1->60 \%$ bedrock or mineral substrate exposed; & 20 & 3.6 \\
\hline & Category $2-60-30 \%$ bedrock or mineral substrate exposed; and & 45 & 8.2 \\
\hline & Category $3-<30 \%$ bedrock or mineral substrate exposed. & 170 & 31.0 \\
\hline & & Total 235 & 42.8 \\
\hline
\end{tabular}



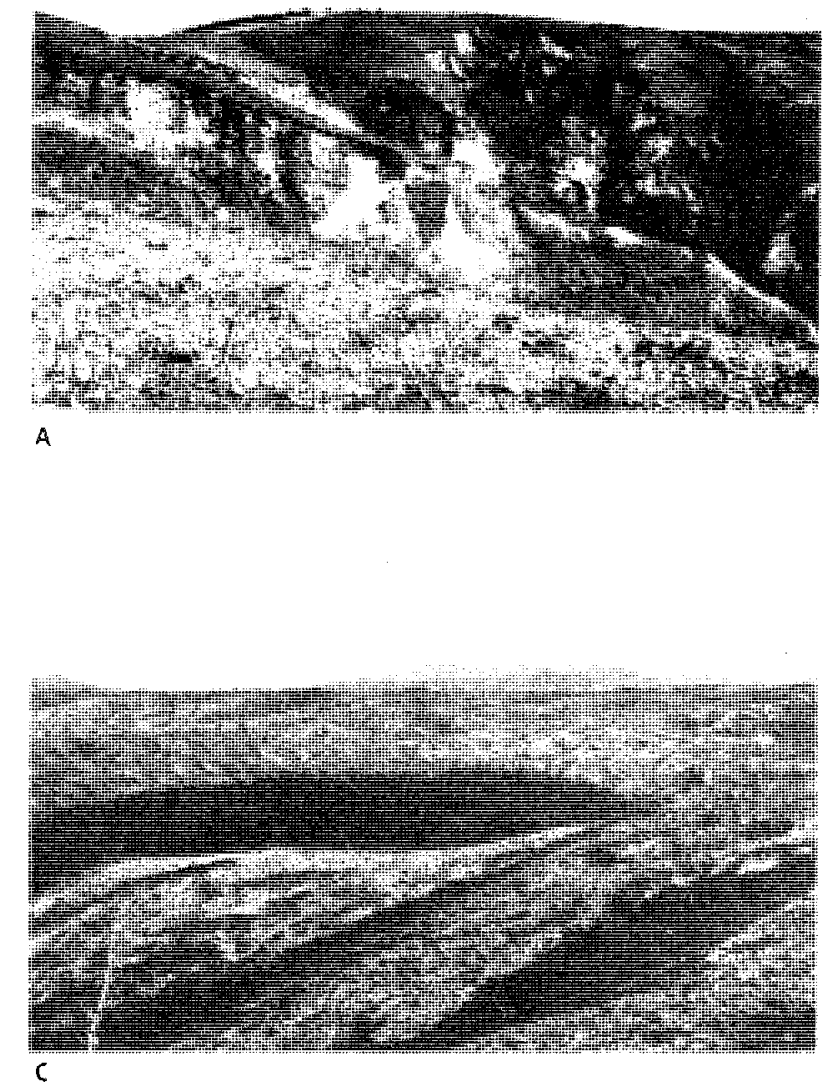
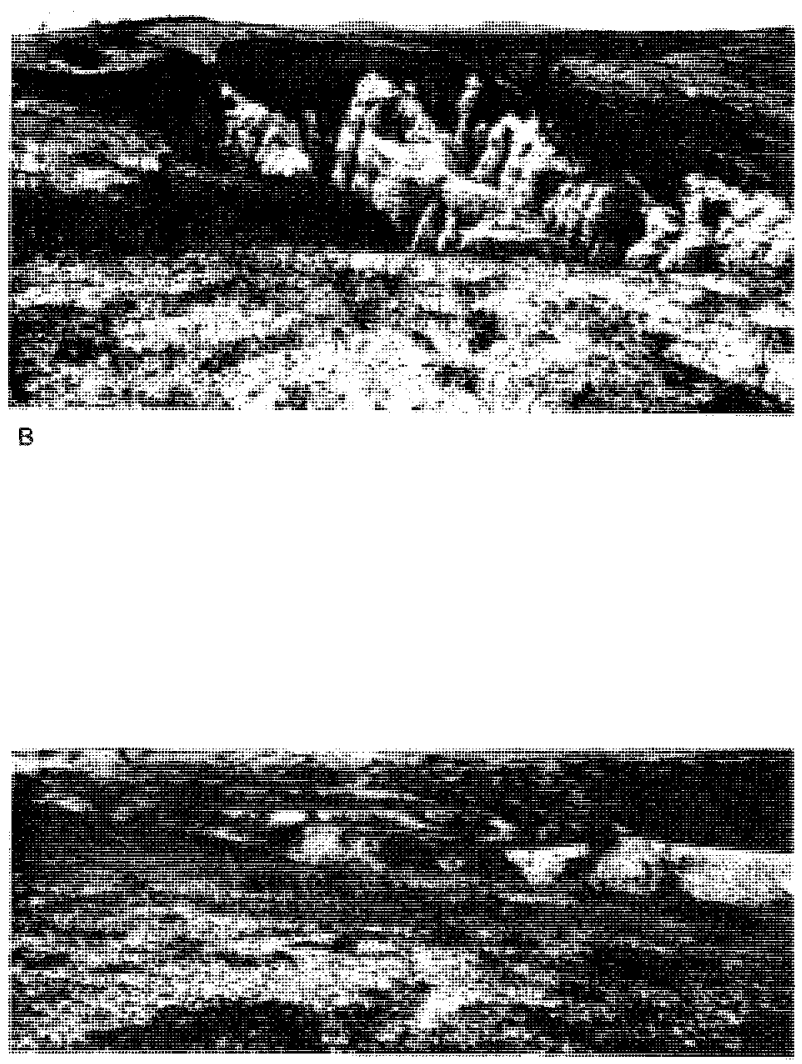

D

PLATE 1

(A) Gullies forming at the headwaters of drainage lines after peat removal. (B) Small gullies coalesce to form larger units. Geology: unconsolidated Tertiary gravels, sands and clays. (C) Severe sheet erosion on well drained positions in the Moores Valley area. (D) Sheet erosion on crests, slopes and ridges near Moores Valley. 


\section{DISCUSSION}

The study area includes some of the most severely eroded and degraded land in southwestern Tasmania. Although firing during aboriginal occupation may have initiated soil erosion it is likely that frequent firing in recent times has intensified this problem. Large tracts of land in the region with organic soils and sedgeland/heath vegetation have been affected by sheet erosion. This includes areas surrounding Point Vivian, the Ironbound Range, Ped Point Hills, the New Harbour Range, Rowitta Plains, Mount Rugby, Lost World Plateau, North Broken Hill and the Lawson Range, Giblin River Plains, Piners Peak and the Denison, De Witt, Erskine and Propsting Ranges. The sedgeland/heath vegetation associated with peat soils in Tasmania is prone to firing due to the flammability of many of the species (such as Gymnoschoenus sphaerocephalus and various Melaleuca, Leptospermum, Baeckia and Boronia spp.), and the hot, dry conditions, which are relatively common during summer.

Firing promotes sheet erosion be removing vegetation which binds the organic soil but more seriously by burning peat and producing an ash that is easily removed by wind and water. Frequent, strong westerly winds, and a high annual average rainfall intensify the problem. Sheet erosion can occur relatively rapidly on peats compared to mineral soils, with destruction of up to $0.2 \mathrm{~m}$ of organic soil in one prescribed burn (Bowman \& Jackson 1981).

Peat absorbs water and reduces the rate of runoff. Therefore any substantial loss of this soil results in increased surface water flow. Reduced vegetation cover on areas of denuded peat intensifies this problem. Both of these factors contribute to the spread and development of sheet and gully erosion.

Gullies appear to have developed in some places after the removal of peat horizons by sheet erosion. The main occurrences are between the Spero and Wanderer Rivers (fig. 1). They have formed on Tertiary gravels, sands, silts and clays which are relatively unconsolidated and vulnerable to erosion. Erosion appears to be removing material from both the headwaters and sides of the gullies.

Large quantities of sediment, derived from gully and sheet eroded areas, is transported into creeks and rivers. This increases the potential for flooding as there is more material in the drainage lines and less peat in the catchments. An increase in organic matter in drainage lines could in some cases lead to cutrophication.
Organic soils are very important nutrient sources in the blanket bogs (Bowman \& Jackson 1981) particularly as they often overlie infertile siliceous substrates. They can be degraded by firing, and some authors have suggested that, although fires have occurred in the region for thousands of years, frequencies have increased over recent times (Kirkpatrick 1983). Although some arise from lightning strikes (Hodge 1983) many result from acts of arson or are started by accident. Such fires are most likely to start during hot, dry summer conditions when peat burns are most likely. Hazard reduction burns have been carried out for the last couple of decades in the region and some have destroyed peat horizons. Organic soils near the Scotts Peak Road were destroyed by a hazard reduction burn (Bowman \& Jackson 1981) while another in the Vale of the Rasselas extended up the slopes of the Denison Range with similar results. Tyson (1983) reported that a hazard reduction burn in the Port Davey area did little damage to root systems as the soil was saturated, which suggests there was little or no loss of peat.

The most recent fire in the study area escaped from a burn intended to create a favourable habitat for the rare orange-bellied parrot. Re-assessment of this kind of land management is needed in a region where it is impossible for the peat-forming process to keep pace with soil loss. It may take decades to restore organic soil cover in the absence of further disturbance. If the area is to be stabilised, attempts must be made to limit firing. If frequent firing continues, peat loss on well drained sites is inevitable, with an increase in gully erosion, sedimentation, and flooding. Some sheet-eroded areas have minor peat accumulations where peat redevelopment could occur. Frequent firing in southwestern Tasmania has consumed organic soil, initiated sheet erosion and reduced the nutrient level of peatlands.

The rate of peat formation has not been measured in the region but it is likely to be extremely slow. Horizons which probably took centuries to form can burn in a few hours Considerable work on aspects of peat ecology, including the extent of peat erosion, rate of peat development, and the effects of prescribed burning on peat, is required if Tasmanian peats and dependent plants and animals are to be appropriately conserved. 


\section{ACKNOWLEDGEMENTS}

John Grant is thanked for his help in the field. The following are acknowledged for their criticism and comments: Ray Carpenter, John Davies, John Grant, Pierre Horwitz, Kevin Kiernan, Fiona Preston, Lindsay Richley, Mike TempleSmith and Steven Smith. John Davies and John Grant are especially thanked for many hours of discussion about vegetation and soils in southwestern Tasmania. The South West Land Systems Survey was conducted by the Chemistry and Soils Section of the Department of Agriculture, Tasmania. Funding for this survey has been provided under the Commonwealth Government National Soil Conservation Programme (NSCP) under the Soil Conservation (Financial Assistance) Act 1985 .

\section{REFERENCES}

BOWMAN, D.M.J.S., 1980: Fire, nutrient and vegetation interactions in South West Tasmania. Unpubl. Hons thesis, Univ. Tasm. Bot.

BOWMAN, D.M.J.S. \& JACKSON, W.D., 1981: Vegetation succession in South West Tasmania. Search 12(10): 358-362.

BOWMAN, D.M.J.S., MACLEAN, A.R. \& CROWDEN, R.K., 1986: Vegetation-soil relations in the lowlands of South West Tasmania. Aust. J. Ecol. 11: $141-153$

BROWN, M.J. \& PODGER, F.D., 1982: Floristics and fire regimes of a vegetation sequence from sedgeland-heath to rainforest at Bathurst Harbour, Tasmania. Aust. J. Bot. 30: 659-676.

DAVIES, J.B., 1983: Huon pine survey 1983. Tech. Rep. 83/2. Tasm. Natl Pks Wildl. Serv.: $46 \mathrm{pp}$.

DAVIES, J.L., 1959: High level erosion surfaces and landscape development in Tasmania. Aust. Geogr. 7: 193-203.

GIBSON, N., 1986: Conservation and management of Huon pine in Tasmania. Tech. Rep. 86/3. Tasm. Natl Pks Wildl. Serv.: 91 pp.
GORE, A.J.P., 1983: ECOSYSTEMS OF THE WORLD 4A - MIRES: SWAMP, BOG, FEN AND MOOR. Elsevier, Amsterdam: $350 \mathrm{pp}$.

GOWLLAND, R. \& GOWLLAND, K., 1975 TRAMPLED WILDERNESS - THE HISTORY OF SOUTH-WEST TASMANIA. Richmond and Sons, Devonport: $160 \mathrm{pP}$.

HODGE, G., 1983: The practical aspects of fire control In Gee, H. \& Fenton, J. (Eds): THE SOUTH WEST BOOK. Australian Conservation Foundation, Collins: $308 \mathrm{pp}$

JONES, R., 1974: Tasmanian tribes. In Tindale, N.B (Ed.): ABORIGINAL TRIBES OF AUSTRALIA ANU Press: appendix.

KIRKPATRICK, J.B., 1983: Fire and plant communities in the South West. In Gee, H. \& Fenton, J. (Fds) THE SOUTH WEST BOOK. Australian Conservation Foundation, Collins: $308 \mathrm{pp}$.

KIRKPATRICK, J.B. \& DICKINSON, K.J.M., 1984 The impact of fire on Tasmanian alpine vegetation and soils. Aust. J. Bot. 32: 613-629.

LARGE, R.R., HERRMAN, W. \& CORBETT, K.D., 1987: Base metal exploration of the Mount Read Volcanics, western Tasmania: part 1. Geology and exploration, Elliott Bay. Econ. Geol. 82(2): 267-289.

PEMBERTON, M., in press: LAND SYSTEMS OF TASMANIA. REGION 7 - THE SOUTH WEST. Department of Agriculture, Tasmania.

PETERS, D.G., 1984: TASFORHAB. In Meyers, K. \& Musto, I. (Eds): PROCEEDINGS OF A WORKSHOP ON SURVEY METHODS FOR NATURE CONSERVATION. CSIRO, Canberra: 179-192.

TYSON, R., 1983: Fire management in National Parks. In Gee, H. \& Fenton, J. (Eds): THE SOUTH WEST BOOK. Australian Conservation Foundation, Collins: $308 \mathrm{pp}$.

WEIN, R.W., 1981: Characteristics and suppression of fires in organic terrain in Australia. Aust. For. $44(3): 162-169$

(accepted 12 February 1988 